\title{
Hubungan Fleksibilitas Otot Tungkai terhadap Kecepatan Tendangan Eolgol Dollyo Chagi
}

\author{
A Relationship of Leg Muscle Flexibility to \\ Eolgol Dollyo Chagi's Kick Speed
}

\author{
Bambang Gatot Sugiarto, Sutan Rizali \\ STKIP Pasundan, Cimahi, Jawa Barat, Indonesia, \\ bambanggatot_sugiarto@yahoo.com
}

\begin{abstract}
Abstrak
Penelitian ini memiliki tujuan ingin mengetahui hubungan fleksibilitas otot tungkai terhadap kecepatan tendangan eolgol dollyo chagi atlet dojang spartan taekwondo Belitung.Metode yang digunakan dalam penelitian ini adalah metode deskriptif kuantitatif korelasional dengan pendekatan one-shoot-case study yaitu pendekatan yang menggunakan satu kali pengumpulan data. Sedangkan untuk melakukan pengujian peneliti menggunakan tes, yaitu peneliti secara langsung melakukan tes dan pengukuran dilapangan. Populasi dalam penelitian ini adalah atlet taekwondo yang berjumlah 30 orang. Dalam penelitian ini banyak sampel sama dengan jumlah populasi sebanyak 30 orang. Teknik pengambilan sampel dalam penelitian ini adalah total sampling. Teknik pengumpulan data yang digunakan dalam penelitian ini penulis menggunakan tes tendangan eolgo dollyo chagi \&Sit and Reach test. Berdasarkan hasil pengolahan dan analisis data, maka dapat disimpulkan sebagai berikut: Terdapat hubungan yang signifikan antara fleksibilitas otot tungkai terhadap kecepatan tendangan eolgol dollyo chagi, yang dilakukan siswa Dojang Spartan Taekwondo Belitung. Besarnya kontribusi fleksibilitas otot tungkai terhadap kecepatan tendangan eolgol dollyo chagi yaitu sebesar $49,44 \%$. Semakin baik fleksibilitas otot tungkai siswa maka semakin baik pula hasil kecepatan tendangan eolgol dollyo chagi.
\end{abstract}

Kata Kunci: Fleksibilitas Otot Tungkai, Tendangan Eolgol Dollyo Chagi.

\begin{abstract}
The purpose of this research is to find out the relationship between limb muscle flexibilityto the speed of dollyo chagi eolgol kicking for spartan taekwondo athletes in Belitung. The method used in this research is descriptive quantitative correlational method with a one-shoot-case study approach that uses one-time data collection. Whereas for testing the researchers used a test, namely the researchers directly carried out tests and measurements in the field. The population in this study were taekwondo athletes totaling 30 people. In this study many samples equal the total population of 30 people. The sampling technique in this study was total sampling. Data collection techniques used in this study the authors used eolgo dollyo chagi \& Sit and Reach test kicks. Based on the results of data processing and analysis, it can be concluded as follows: There is a significant relationship between limb muscle flexibility towards the speed of dollyo chagi eolgol kick, which is done by Dojang Spartan Taekwondo students in Belitung. The magnitude of the contribution of leg muscle flexibility to the speed of dollyo chagi eolgol is equal to 49.44\%. The better the flexibility of students' leg muscles, the better the results of the dollyo chagi eolgol kick speed.
\end{abstract}

Keywords:Leg Muscle Flexibility, Eolgol Dollyo Chagi's Kick 


\section{PENDAHULUAN}

Taekwondo adalah olahraga bela diri modern yang berasal dari korea. Taekwondo berasal dari kata tae, yaitu kaki artinya menghancurkan dengan tendangan, kwon yaitu tangan artinya menghantam dan mempertahankan diri sedangkan, do berarti seni mendisiplikan diri. Dengan demikian taekwondo artinya seni bela diri yang menggunakan teknik kaki dan tangan kosong. Teknik dasar yang harus dipelajari setiap taekwondo yaitu teknik kuda-kuda, pukulan, tendangan dan tangkisan. Sedangkan materi terpenting dalam berlatih taekwondo, yaitu poomsae, kyukpa dan kyorugi.

Tendangan dalam taekwondo biasa disebut dengan chagi. Bagi pemula dalam beladiri taekwondo harus mengetahui teknik atau jenis tendangan dasar yang digunakan dalam pertahanan diri. Berikut jenis-jenis tendangan / Chagi yang wajib diketahui dan pelajari, yaitu :Ap Chagi,Dollyo chagi, Deol chagi,Yeop chagi,Dwi Chagi, Dwi Hurigi,Narae Chagi,Dolke Chagi.

Di antara teknik-teknik tendangan taekwondo tersebut yang menjadi salah satu pusat permasalahan yang akan dikaji dalam penelitian ini adalah mengenai tendangan eolgol dollyo chagi. Tendangan eolgol dollyo-chagi adalah tendangan yang dilakukan dengan arah gerak melingkar, dengan putaran pinggang dan menggunakan kekuatan otot tungkai kearah atas dengan perkenaan bagian kura-kura kaki dan sasaran tendangan yaitu seluruh bagian kepala yang dalam perlindungan (Yoyok, 2009). Tendangan dollyo chagi sendiri merupakan salah satu tendangan dasar dalam bela diri taekwondo, karena tendangan ini merupakan tendangan yang mudah untuk menghasilkan poin saat bertanding dan power tendangan yang dihasilkan juga sangat besar, maka banyak taekwondo yang sering melakukan tendangan ini pada saat pertandingan kyorugi.

Untuk melakukan berbagai tendangan taekwondo, terutama pada tendangan eolgol dollyochagi maka perlu ditunjang oleh komponen-komponen kondisi fisik yang baik seperti kekuatan, kelentukan, daya tahan, kecepatan, dan power. Dari kelima komponen kondisi fisik tersebut diatas. Kecepatan merupakan salah satu komponen yang penting dalam pencapaian prestasi. Upaya-upaya atlet dalam meningkatkan prestasi khususnya kecepatan merupakan hal yang strategis (Sukadiyanto, 2010).

Dalam cabang olahraga taekwondo, kecepatan merupakan kondisi fisik yang esensial dan merupakan faktor penentu terutama saat atlet berada dalam situasi pertandingan. Hal ini didasarkan pada tuntutan pertandingan olahraga taekwondo yang biasanya berlangsung dinamis dan cepat. serta agar lawan tidak memiliki kesempatan untuk melakukan hindaran, dan balasan (Tirtawirya, 2009).

Namun, keterkaitannya dengan kecepatan pada tendangan dalam taekwondo, peran anatomis yang tidak bias dikesampingkan guna mendukung kemampuan kecepatan tendangan seorang atlet taekwondo adalah fkesibilitas. Fleksibilitas tubuh sangat berpengaruh dan memberikan sumbangan positif dalam gerakan taekwondo, khususnya saat melakukan tendangan. Fleksibilitas sendiri 
merupakan kemampuan dari sebuah sendi, otot, dan ligamen di sekitarnya untuk bergerak dengan leluassa dan nyaman dalam ruang gerak maksimal yang diharapkan (Renold, et al, 2015).

Taekwondoin yang fleksibel adalah taekwondoin yang mempunyai ruang gerak yang luas dalam sendi-sendinya dan yang mempunyai otot-otot elastis. Orang yang otot-otot kaku, tidak elastis, biasanya terbatas dalam melakukan gerakan khususnya tendangan oleh karena itu, taekwondoin harus mempunyai tingkat elastisitas yang baik persendiannya. Hal ini dikarenakan gerak teknik pada tendangan dalam olahraga taekwondo sangat menuntut tingkat fleksibilitas tinggi. Apabila taekwondoin memiliki hal tersebut maka akan dengan mudah melakukan gerak teknik tendangan dengan berbagai arah. Dalam upaya untuk melakukan teknik tendangan yang sangat baik, otot tungkai adalah otot yang dominan dan harus memiliki tingkat fleksibilitas yang tinggi.

Pentingnya fleksibilitas otot tungkai terhadap kecepatan tendangan dalam olahraga taekwondo dikarenakan gerakan dalam olahraga taekwondo sangat memerlukan kelenturan tubuh yang baik, terutama dalam hal tendangan. Tendangan yang dilatih dalam taekwondo lebih banyak memfokuskan serangan kearah kepala, sehingga jika siswa tidak memiliki kelenturan yang baik, maka akan sangat susah melakukan gerakan tendangan bahkan bisa berpotensi menimbulkan cedera dan tenaga yang dikeluarkan pasti akan jauh lebih besar. Fleksibilitas sangat berpengaruh dalam hal nya melakukan tendangan eolgol dollyo chagi karena kelenturan saling berkaitan dengan proses melakukan kecepatan tendangan eolgol dollyo chagi yang memiliki peranan besar dalam pertandingan taekwondo kategori kyourugi, terutama untuk mencuri poin disetiap rondenya (Suharjana, 2012).

Untuk membahas keterkaitan hal-hal tersebut dan memperoleh data serta bukti yang empiris, perlu kiranya penulis meneliti mengenai keterkaitan antara fleksibilitas otot tungkai dengan kecepatan tendangan eolgol dollyo chagi.

\section{METODOLOGI PENELITIAN}

Dalam penelitian ini penulis menggunakan metode deskriptif kuantitatif korelasional. Metode penelitian yang berlandaskan pada filsafat positivisme, digunakan untuk meneliti pada populasi atau sampel tertentu, pengumpulan data menggunakan instrumen penelitian, analisis data bersifat kuantitatif/statistik, dengan tujuan untuk menguji hipotesis yang telah ditetapkan.

Untuk itu penulis menggunakan pendekatan one-shoot-case study yaitu pendekatan yang menggunakan satu kali pengumpulan data (fraenkel, et al, 2012). Sedangkan untuk melakukan pengujian peneliti menggunakan tes yang secara langsung dilakukan di lapangan.

Pada penelitian ini variabel terikat yaitu kecepatan tendangan eolgol dollyo chagi dan variabel bebas yaitu fleksibilitas otot tungkai. Populasi dalam penelitian ini yaitu dojang spartan 
taekwondo Belitung yang terdiri dari 30 orang, yang semuanya dipergunakan sebagai sampel penelitian melalui teknik total sampling.

Sementara itu, instrumen yang penulis gunakan untuk memperoleh data penelitian yaitu tes tendangan eolgol dollyo chagi yang digunakan untuk mengukur kemampuan tendangan eolgol dollyo chagi yang memiliki nilai reliabilitas sebesar 0,989. Prosedur pelaksanaannya yaitu tester menendang sesuai ukuran tinggi badan pada sasaran yang menjadi batas sasaran yaitu kepala sesuai tinggi masing-masing tester. Tendangan yang dicatat pun harus berbunyi keras dan tepat sasaran, dilakukan selama 30 detik dan untuk mengurur tingkat fleksibilitas sampel, penulis menggunakan instrument sit and reach.

\section{HASIL DAN PEMBAHASAN}

\section{Hasil}

Setelah melakukan pengambilan data menggunakan instrument tes tendangan dan te fleksibilitas menggunaka instrument sit and reach, kemudian data tersebut diolah menggunakan uji statistik, yaitu uji-t yang hasilnya dapat dilihat pada tabel 1 di bawah ini :

Tabel 1

Hasil uji fleksibilitas otot tungkai dan kecepatan tendangan eolgol dollyo chagi

\begin{tabular}{|c|c|}
\hline Thitung $_{\text {hisel }}$ & T $_{\text {tabel }}$ \\
\hline 5,23 & 2,048 \\
\hline
\end{tabular}

Dari data tersebut diperoleh nilai $\mathrm{T}_{\text {hitung }}$ sebesar 5,23 dan nilai dari $\mathrm{T}_{\text {tabel }}$ sebesar 2,048. Kriteria pengujian adalah terima $\mathrm{H} 0$ apabila nilai $\mathrm{T}_{\text {hitung }} \leq \mathrm{T}_{\text {tabel }}$ dan tolak $\mathrm{H} 0$ apabila $\mathrm{T}_{\text {hitung }}>\mathrm{T}_{\text {tabel. }}$. Karena hasil $\mathrm{T}_{\text {hitung }}(5,23)$ lebih besar dari nilai $\mathrm{T}_{\text {tabel }}(2,048)$ maka menjelaskan bahwa fleksibilitas otot tungkai memiliki hubungan yang signifikan dengan kecepatan tendangan eolgol dollyo chagi.

Kemudian untuk mengetahui sejauh mana hubungan antara kedua variabel tersebut, dilakukan uji indeks determinasi hubungan antara fleksibilitas otot tungkai dengan kecepatan tendangan eolgol dollyo chagi, dan hasilnya diperoleh sebesar 49,44\%. Hal tersebut artinya siswa yang memiliki tungkai yang panjang memberikan dukungan terhadap terhadap kecepatan tendangan eolgol dollyo chagi sebesar 49,44\% dan ada faktor lain yang mendukung terhadap kecepatan tendangan eolgol dollyo chagi sebesar 50,56\% selain dari faktor fleksibilitas otot tungkai.

\section{Pembahasan}

Fleksibilitas adalah kemampuan untuk beradaptasi dan bekerja dengan efektif dalam situasi yang berbeda, dan dengan berbagai indvidu atau kelompok. Fleksibilitas merupakan efektivitas seseorang dalam menyesuaikan diri untuk segala aktivitas dengan penguluran tubuh pada bidang 
sendi yang luas. Ini berarti fleksibilitas merupakan kemampuan seseorang untuk dapat melakukan gerak dengan ruang gerak seluas-luasnya dalam persendiannya (Yudiana, 2011; Rahmawati, 2015; Suharjana, 2013).

Dalam olahraga taekwondo, fleksibilitas otot sangat diperlukan guna menunjang efektifitas serta kemampuan teknik gerakannya. Kemampuan teknik tendangan eolgol dollyo chagi salah satunya. Teknik yang paling mudah dan paling efektif untuk mendulang poin dalam olahraga taekwondo ini (Widyasari, 2009), disamping memerlukan kecepatan yang sangat baik, seorang taekwondoin juga harus memiliki kemampuan fleksibilitas otot yang bagus, dalam hal ini otot tungkai yang dominan.

Hasil penelitian ini menunjukkan bahwa kemampuan fleksibilitas seorang taekwondoin sangat erat kaitannya terhadap kecepatan menendang mereka. Indeks determinasi sebesar 49,44\% menunjukkan bahwa fleksibilitas otot tungkai ini memiliki hubungan dan determinasi yang sangat tinggi terhadap kecepatan tendangan eolgol dollyo chagi seorang taekwondoin. Hasil penelitian ini juga sejalan dengan hasil penelitian sebelumnya yang mengemukakan keerkaitan antara fleksibilitas oto dengan kemampuan tendangan dalam olahraga taekwondo (rozikin, 2015).

\section{Kesimpulan}

Berdasarkan hasil penelitian di atas, yang mengemukakan bahwa adanya hubungan signifikan antara fleksibilitas otot tungkai dengan kecepatan tendangan eolgol dollyo chagi, dapat ditarik kesimpulan bahwa kemampuan seorang atlet taekwondo tidak hanya ditunjang oleh keterampilan teknik dan kemampuan fisik seperti kecepatan saja, melainkan kemampuan fisik lainnya yaitu fleksibilitas juga ikut menunjang terhadap performa atlet tersebut.

Maka dari itu seorang pelatih perlu melihat dan menyadari tentang peranan fleksibilitas otot bagi atletnya ini, proses latihan yang dilengkapi dengan latihan fleksibilitas akan sangat berdampak bagi peningkatan performa atletnya.

\section{DAFTAR PUSTAKA}

Fraenkel, et al. (2012).How to Design and Evaluate Research in Education. New York: McGraw Hill.

Rahmawati, Yuliana. (2015). Pengaruh Latihan Swiss Ball Terhadap Peningkatan Trunk Pada Remaja Putri Usia 17-21 Tahun, Interest: Jurnal Ilmu Kesehatan. Vol. 4 No.1

Renold, C.I., et al. (2015). Pengaruh Latihan Peregangan Terhadap Fleksibilitas Lansia. Jurnal eBiomedik. Vol. 3 (I).

Rozikin, Ali.(2015). Hubungan Fleksibilitas dan Kekuatan Otot Tungkai terhadap Hasil Tendangan Eolgol Dollyo-Chagi pada Olahraga Taekwondo. Journal of Sport Sciences and Fitness. Semarang: Universitas Negeri Semarang. 
Suharjana. (2012). Pendidikan Kebugaran Jasmani: PedomanKuliah. Yogyakarta: FIK Universitas Negeri Yogyakarta.

Suharjana. (2013). Kebugaran Jasmani. Yogyakarta: Jogja Global Media. Suharjana. Latihan Beban. (Yogyakarta: FIK UNY. 2009

Sukadiyanto. (2010). Pengantar Teori Dan Melatih Fisik. Yogyakarta: FIK Universitas Negeri Yogyakarta.

Tirtawirya. (2011). Diktat Melatih Fisik Taekwondo. Yogyakarta: FIK Universitas Negeri Yogyakarta.

Widyasari, Giri Kurnia. (2009) Identifikasi Teknik Tendangan yang Dominan dalam Pertandingan Taekwondo Kejuaraan Mahasiswa Nasional Piala Presiden XI Tahun 2009. Skripsi FIK Universitas Negeri Yogyakarta

Yoyok, Suryadi \& Vincentius. (2009). Poomsae Taekwondo untuk Kompetisi. Gramedia.

Yudiana, Yuyun. (2011). Latihan Fisik. Bandung: Fakultas Pendidikan Olahraga dan Kesehatan Universitas Pendidikan Indonesia. 